\title{
Prof. Leif Rogers: the recent advances in implant breast reconstruction and fat grafting
}

Submitted Sep 18, 2019. Accepted for publication Nov 25, 2019.

doi: 10.21037/atm.2019.11.147

View this article at: http://dx.doi.org/10.21037/atm.2019.11.147

\section{Editor's note}

From August $17^{\text {th }}$ to $18^{\text {th }}, 2019$, the $1^{\text {st }}$ China-USA International Medical Summit was held at the China National Convention Center in Beijing, China. The conference aimed to create a global health platform for clinical cooperation between China and the USA, for the purpose of supporting medical education in China and contributing to the "Health Silk Road" initiative. As one of the sponsorship partners of the conference, AME was honored to conduct an interview with Prof. Leif Rogers from the Cedars-Sinai Medical Center. Prof. Leif is also a founder of the Core Healing Center in Beverly Hills.

\section{Expert's introduction}

Leif Rogers, MD, FACS (Figure 1), is an Ivy League graduate and a board certified plastic and reconstructive surgeon. He specializes in microsurgical reconstruction of the breast and the latest techniques in facial rejuvenation and body contouring. Dr. Rogers has received grants from several institutions, his academic research has been published in a number of medical journals, and he has been the recipient of numerous awards. Dr. Rogers donates his time by working with HELP International to deliver charitable surgical services worldwide.

\section{Interview (Figure 2)}

ATM: You are going to give us a speech on advances in implant breast reconstruction and fat grafting. Could you give us an introduction to it?

Prof. Rogers: One of my lectures is going to be on the advances in implant breast reconstruction and fat grafting. I think it's an important topic because how we do breast reconstruction in the United States has changed quite a bit in the last decade or so. Tissue expander and implants have been around for quite some time, and of course we can do big free flap and microsurgical procedures. I know the

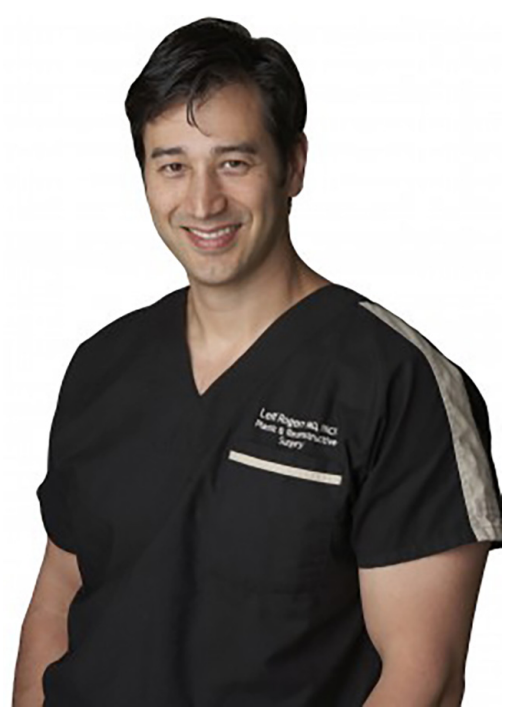

Figure 1 Leif Rogers, MD, FACS.

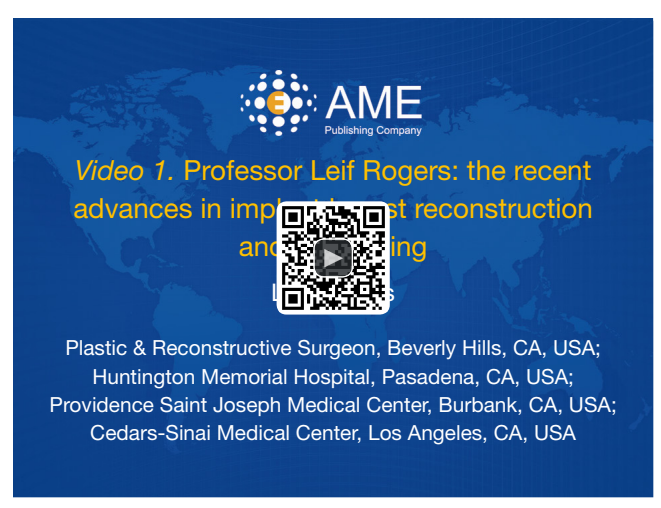

Figure 2 Professor Leif Rogers: the recent advances in implant breast reconstruction and fat grafting (1).

Available online: http://www.asvide.com/watch/33102

microsurgical procedures are very common here in China, because there are some very good microsurgeons here. But from my understanding, the reconstructive techniques using implants in fat grafting aren't as common. The reason why I 
think it's worthwhile is because it's much more applicable to all patients now. In the past it was limited. You couldn't get as nice results, and if you had radiation you really shouldn't do it or you had to do a bigger procedure. But, with the advent of fat grafting, you can improve the quality of the tissues and you can make breasts look so much better than they ever were before with just an implant. We also have shaped implants now which are anatomically much nicer looking than the round ones. However, there are now some new issues with the texture which I'll talk about very briefly in the lecture.

\section{ATM: Could you share with us some of the recent research projects that you are involved in?}

Prof. Rogers: I'm involved in a number of companies and in their products. So, I help them develop their products and develop how best to use them. It includes certain devices or radio frequency type devices. But I think the one that's the most interesting is Renuva. Renuva is made by a company in the US called MTF. It's a human product made from cadavers. They take the fat layer under the skin and they turn it into a powder with growth factors in it. When you inject it into a living person it will signal your stem cells to differentiate and divide and turn into your own new fat cells, which is something we haven't been able to do before.

\section{ATM: What is the most impressive clinical case of implant or reconstruction in your career?}

Prof. Rogers: Now when it comes to reconstructive cases I've done many, so many. It's hard for me to remember. Probably some of the most impressive cases I did were actually back in residency, because in residency we saw some of the big, horrible, horrible cases. We had this one patient who had tried to commit suicide. He took a gun and put it here (Prof. Rogers points to Chin) to kill himself. But when he pulled the trigger he didn't kill himself. He just blew his entire face off. So, we had to reconstruct his entire face, which was interesting. We had to rebuild everything in the middle portion here (Prof. Rogers points to Chin), which had many, many plates and little fragments of bone.
Unfortunately, we couldn't give him his eyes back because he had completely destroyed them. But we were able to reconstruct the lower portions of his face so he could eat. And most interestingly, after all this, you would think that he would want even more to end his life, but in fact, he found a new lease on life. He wanted to live now.

\section{ATM: Do you bave any suggestions for young doctors and students working in or interested in this field?}

Prof. Rogers: For those medical students out there or residents who are thinking about going into plastic surgery or just really into medicine at all, they should know it's a rapidly growing field, and I think China is a fascinating place to do this now. Things are changing so quickly here it's hard to know where it's all going to end up. I do believe that the future is bright if you are interested in having a private practice which is very different than in the US. In the US, private practice is slowly disappearing because the insurance companies are making it harder and harder. I think in China it actually may be the opposite. So look into how you can develop private practice and own your own clinics and surgery centers. I think that may be the future for medicine in China.

\section{Acknowledgments}

None.

\section{Footnote}

Conflicts of Interest: The authors have no conflicts of interest to declare.

\section{References}

1. Yang K, Zhou A. Professor Leif Rogers: the recent advances in implant breast reconstruction and fat grafting. Asvide 2020;7:062. Available online: http://www.asvide. $\mathrm{com} / \mathrm{watch} / 33102$

(Science Editors: Karina Yang, Angelia Zhou, ATM, editor@atmjournal.org)
Cite this article as: Yang $\mathrm{K}$, Zhou A. Prof. Leif Rogers: the recent advances in implant breast reconstruction and fat grafting. Ann Transl Med 2020;8(4):147. doi: 10.21037/ atm.2019.11.147 